\title{
An approach to optimize pre-annealing aging and anneal conditions to improve photovoltaic performance of perovskite solar cells
}

\author{
Dahiru M. Sanni ${ }^{1,2}$. Yuanqing Chen ${ }^{3}$. Aditya S. Yerramilli ${ }^{3}$. Esidor Ntsoenzok ${ }^{4,5}$. Joseph Asare ${ }^{1,6}$. \\ Sharafadeen A. Adeniji ${ }^{1}$. Omolara V. Oyelade ${ }^{1}$. Adebayo A. Fashina ${ }^{1}$ - T. L. Alford ${ }^{3,5}$
}

Received: 10 August 2018 / Accepted: 10 December 2018 / Published online: 19 December 2018

(c) The Author(s) 2018

\begin{abstract}
In this study, we reported a low-temperature, one-step solution process to fabricate perovskite solar cells using dehydrated lead acetate as the lead source. These perovskite films were aged at $200 \mathrm{~s}$ before thermal annealing at $90{ }^{\circ} \mathrm{C}$ for $5 \mathrm{~min}$. Uniform perovskite films with lesser pinholes were obtained by this technique. The inverted planar (n-i-p) perovskite solar cell device resulted in a power conversion efficiency of $13 \%$. A substantial finding was that the devices demonstrated high reproducibility. We also investigated the effect of annealing temperature on the optical and structural properties of the films and on the photovoltaic performances of the fabricated solar cell devices. For the aforementioned, a low-temperature, onestep solution process, the optimal temperature was achieved at $90^{\circ} \mathrm{C}$.
\end{abstract}

Keywords Dehydrated lead acetate $\cdot$ Aging time $\cdot$ Perovskite solar cells

\section{Introduction}

The organic-inorganic halide perovskite solar cells have continued to attract serious research interest since the first introduction as solar light by Miyasaka and co-workers with a power conversion efficiency (PCE) of $3.8 \%$ in 2009 to over $22 \%$. This outcome is due to the tremendous advantages of

Electronic supplementary material The online version of this article (https://doi.org/10.1007/s40243-018-0139-3) contains supplementary material, which is available to authorized users.

T. L. Alford

TA@asu.edu

1 Department of Theoretical and Applied Physics, African University of Science and Technology, Abuja, Nigeria

2 Department of Physics, Federal University Dutsin-Ma, Dutsin-Ma, Katsina State, Nigeria

3 School for Engineering of Matter, Transport and Energy, Arizona State University, Tempe, AZ 85287, USA

4 CEMHTI-CNRS Site Cyclotron, 3A rue de la férollerie, 45071 Orléans, France

5 Department of Material Science and Engineering, African University of Science and Technology, Abuja, Nigeria

6 Physics Department, Faculty of Computing and Applied Sciences, Baze University, Abuja, Nigeria the perovskite materials (e.g., as the tunable bandgap, direct bandgap, large optical absorption coefficient, high charge carrier mobilities, low exciton binding energy, and costeffective solution processable [1-4]). Different structures of perovskite solar cells have been investigated and reported extensively in recent years which include perovskite sensitized solar cells $[5,6]$, mesoscopic perovskite solar cells [1, $2,7]$ and planar heterojunction perovskite solar cells [8-10]. The simplest structure of all these devices is the planar heterojunction perovskite solar cells; this is because they are low-temperature processed as compared to mesoporous layers which are high-temperature processed [11]. A great research interest has been devoted to the inverted planar heterojunction perovskite solar cells ( $p-i-n)$ architecture as a significant type of perovskite solar cells. Besides their very low hysteresis when compared to the n-i-p planar heterojunction devices [12], the p-i-n structure can also be produced by a low-temperature solution process employing poly(3,4-ethylenedioxythiophene)/poly(styrenesulfonic acid) (PEDOT:PSS) films for the hole transport layers, which is compatible with flexible substrates for flexible solar cell applications [13].

Different techniques have been employed for the preparation of perovskite films, including vapor deposition [13], vapor-assisted solution process [14], solution process via one-step [1, 15] and two-step sequential deposition [16]. 
Both the single-step deposition as well as the two-step sequential spin coating are solution-processed that require thermal annealing, and are suitable in mass and cost-effective production. Hence, the composition of the precursor solution, the rate of evaporation of the by-product from the film and the annealing temperature have a direct influence on the rate of crystallization, size of the crystals and film morphologies [17]. At the early phases of spin coating, the solvent vaporizes rapidly, and the crystallization rate of the perovskite is greatly lowered due to the presence of the surplus organic constituent in the film; however, the crystallization procedure can further be improved by thermal anneal process of the film to evaporate the surplus organic by-product [18]. During this process, the combinatory by-product of the anneal and evaporation results in pinhole formation within the final crystalline layer. However, by manipulating successfully the growth of the perovskite layer and the nucleation an excellent perovskite film can be obtained by one-step spin coating method; thus, controlling the crystallization process and the dynamics of film formation during coating, before annealing and during annealing are important to the optimization of film morphology. Based on this consideration different approaches have been developed from the areas of precursor selection [18-22], solvent engineering and solvent annealing [23, 24], fast deposition-crystallization [25], thermal annealing [26], interface engineering [27] and processing additive $[8,28]$.

Recently, lead acetate $\left[\mathrm{Pb}(\mathrm{Ac})_{2}\right]$ has been used as the lead source in the preparation of perovskite films by onestep spin coating process [29-31]. One of the advantages of $\mathrm{Pb}(\mathrm{Ac})_{2}$ is that it accelerates the crystal growth of perovskite due to the facile removal of $\mathrm{N}$-methylammonium acetate $\left(\mathrm{CH}_{3} \mathrm{NH}_{3} \mathrm{Ac}\right)$ [32]. As a result, smooth films with fewer pinholes are achieved, which result in a better device performance.

Herein we report the preparation of a one-step, low-temperature solution process to produce smooth $\mathrm{CH}_{3} \mathrm{NH}_{3} \mathrm{PbI}_{3}$ layers free of pinholes, with dehydrated $\mathrm{Pb}(\mathrm{Ac})_{2}$ as the source material. Excellent perovskite films can be obtained by pre-thermal anneal aging for $200 \mathrm{~s}$ before thermal annealing at $90{ }^{\circ} \mathrm{C}$ for $5 \mathrm{~min}$, which can deliver high power conversion efficiency (PCE) of $13.02 \%$ with high repeatability of the device. Only a few works have been done using dehydrated lead acetate as the source material. This may have been attributed to its low repeatability.

\section{Experimental}

\section{Materials}

Lead acetate trihydrate $\left(\mathrm{PbAc}_{2} \bullet 3 \mathrm{H}_{2} \mathrm{O}\right)$ was purchased from Alfa Aesar, while methylammonium iodide (MAI) was obtained from Dyesol. The dehydrated lead acetate $\left[\mathrm{Pb}(\mathrm{Ac})_{2}\right]$ was obtained by the dehydration of $\mathrm{PbAc}_{2} \bullet 3 \mathrm{H}_{2} \mathrm{O}$ under a flowing nitrogen gas at $80{ }^{\circ} \mathrm{C}$. The precursor was prepared by dissolving $3.0 \mathrm{mmol} \mathrm{MAI}$ and $1.0 \mathrm{mmol}$ $\mathrm{Pb}(\mathrm{Ac})_{2}$ in $1 \mathrm{~mL}$ dimethylformamide (DMF) solvent.

\section{Device fabrication}

The architecture of the solar cell devices was ITO/ PEDOT:PSS/CH $\mathrm{H}_{3} \mathrm{NH}_{3} \mathrm{PbI}_{3} / \mathrm{PCBM} / \mathrm{Ag}$. The patterned glass/ indium tin oxide (ITO) substrates were cleaned in a soap solution, deionized water, acetone and isopropyl alcohol in an ultrasonic bath for $14 \mathrm{~min}$. Finally, they were treated by exposing to ultraviolet-ozone (UVO) for $14 \mathrm{~min}$ to get rid of any remaining impurity. The hole transport layer of PEDOT:PSS was filtered through a $0.45 \mu \mathrm{m}$ filter and the filtered solution was spin coated onto the patterned ITO substrates at a spin-coating rate of $4000 \mathrm{rpm}$ for $60 \mathrm{~s}$ before annealing at $135{ }^{\circ} \mathrm{C}$ for $15 \mathrm{~min}$. The solutions of MAI: $\mathrm{Pb}(\mathrm{Ac})_{2}$ were then spin coated on the PEDOT:PSS layer at the rate of $4000 \mathrm{rpm}$ for $60 \mathrm{~s}$ before they were thermally annealed on the hot plate at the temperatures of $80^{\circ} \mathrm{C}$, $85^{\circ} \mathrm{C}, 90^{\circ} \mathrm{C}$ and $95^{\circ} \mathrm{C}$ for $5 \mathrm{~min}$, respectively. These processes resulted in perovskite films.

After that, the electron collection layer of phenyl- $\mathrm{C}_{61}$-butyric acid methyl ester (PCBM, Aldrich) was obtained by dissolving the solutes into a chlorobenzene solvent $(20 \mathrm{mg} /$ $\mathrm{mL}$ ) and spin coating it on $\mathrm{CH}_{3} \mathrm{NH}_{3} \mathrm{PbI}_{3}$ layer at the rate of $1500 \mathrm{rpm}$ for $30 \mathrm{~s}$. Lastly, the silver $(\mathrm{Ag})$ electrode was deposited on the PCBM to complete the device fabrication process. The fabricated device is an inverted planar heterojunction solar cell (see Fig. 1b). The dimension of the substrate is $2.5 \mathrm{~cm} \times 2.5 \mathrm{~cm}$ and the active area is $0.2 \mathrm{~cm}^{2}$. These sets of devices were vetted to determine the optimal thermal annealing temperature. The next set of devices was for determining the optimal pre-thermal annealing aging time.

In this set of devices the same experimental procedure was followed as explained above, but after the deposition of the $\mathrm{Pb}(\mathrm{Ac})_{2}$ :MAI solutions the films were allowed to age for $0 \mathrm{~s}, 200 \mathrm{~s}$ and $600 \mathrm{~s}$ before they were thermally annealed at $90{ }^{\circ} \mathrm{C}$ for $5 \mathrm{~min}$. After that, the PCBM solution was obtained by dissolving its $20 \mathrm{mg} / \mathrm{mL}$ in a chlorobenzene. The PCBM solution was then spin coated on the perovskite layer at the rate of $1500 \mathrm{rpm}$ for $30 \mathrm{~s}$ to obtain the electron collection layer. Finally, the silver (Ag) electrode was deposited on the PCBM to complete the device fabrication process.

\section{Device characterization}

The samples were characterized by scanning electron microscopy (SEM) to observe the surface morphologies of the samples [SEM-XL30 Environmental FEG (FEI)]. The Cary 5000 UV/VIS spectrometer was used for measuring 
(a)

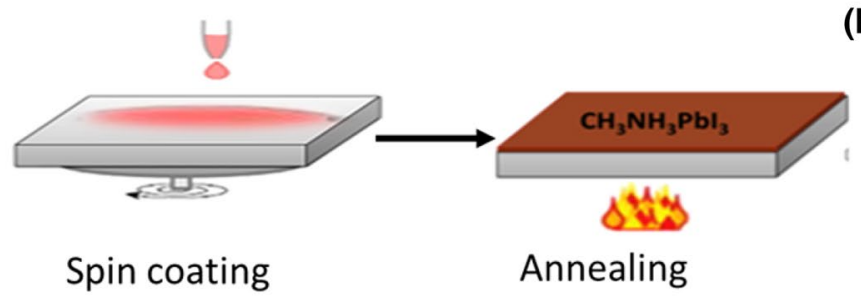

(b)

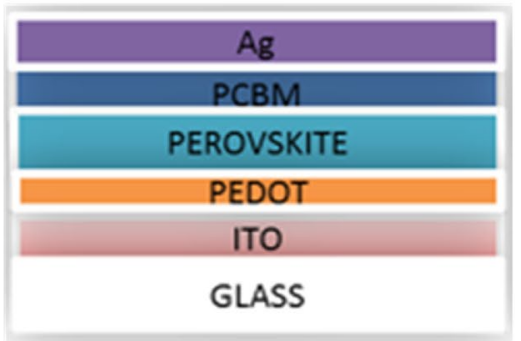

(c)

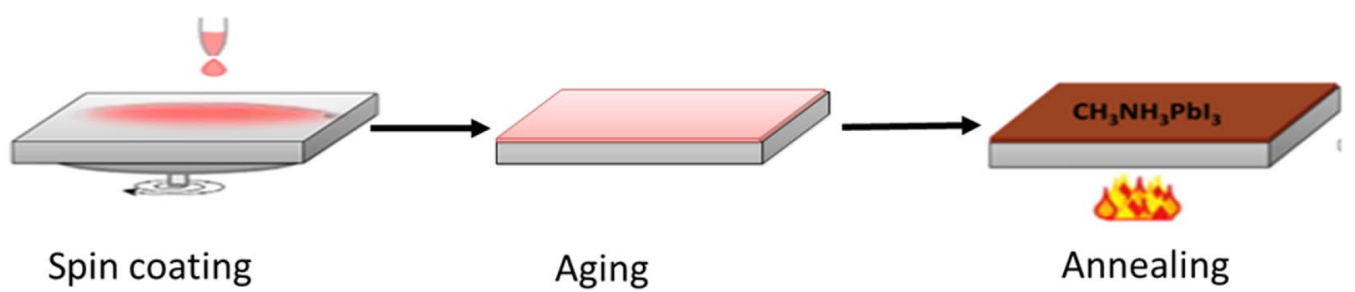

Fig. 1 A schematic representation of the perovskite solar cell fabrication process, a thermal annealing immediately after spin coating, $\mathbf{b}$ the architecture of the device, $\mathbf{c}$ pre-annealing aging after spin coating

the absorption spectra. The X-ray diffraction (XRD) patterns were observed by diffractometer $(40 \mathrm{kV}$ tension and $40 \mathrm{~mA}$ filament current) using $\mathrm{Cu} \mathrm{K} \alpha$ radiation at a stepsize of $0.01^{\circ}$. The current density-voltage $(J-V)$ values of the fabricated solar cells were observed on a Keithley 2400, under simulated AM1.5G irradiation $\left(100 \mathrm{~mW} / \mathrm{cm}^{2}\right)$ with a Xenon-lamp-based solar simulator (Spectra Physics, Oriel Instruments, USA).

\section{Results and discussion}

The SEM images representing morphologies of the perovskite films on ITO/PEDOT:PSS substrates are shown in Figs. 2 and 3. Figure 2a-d shows the morphologies of films obtained with a thermal annealing at temperatures of 80 , 85,90 and $95^{\circ} \mathrm{C}$ for $5 \mathrm{~min}$, respectively. The entire samples show uniform film coverage irrespective of the annealing temperature, however, the crystallinity improves with temperature, and the uniform film coverage observed in all the samples is one of the advantages of lead acetate as a source material for perovskite solar cells. Figure $2 \mathrm{a}-\mathrm{b}$ shows dense film coverage with poor crystal growth and small grain sizes. The poor morphologies observed are attributed to the incomplete evaporation of the by-products methyl ammonium acetate $\left(\mathrm{CH}_{3} \mathrm{NH}_{3} \mathrm{Ac}\right)$ from the films annealed at temperatures of 80 and $85{ }^{\circ} \mathrm{C}$. As a result of the insufficient annealing temperature and annealing time [16, 17], the by-products present in the films create sites for pinholes and poor crystal formation which are caused by the decomposition of $\mathrm{CH}_{3} \mathrm{NH}_{3} \mathrm{Ac}$ in the film. Moore et al. reported that four stages are involved in the formation of perovskite films: vaporization of the solvent, spreading of the surplus irrelevant salt out of the precursor, removal of the unwanted salt from the film and evaporation of stoichiometric MAI from the perovskite lattice [33]. These steps happened during spin coating, aging and annealing process. During spin coating, solvents are evaporated out of the solution; however, some of the solvents will remain in the solution which requires annealing for the complete removal of the solvent (DMF). The evaporation rate of the volatile by-products $\left(\mathrm{CH}_{3} \mathrm{NH}_{3} \mathrm{Ac}\right)$ has a great impact on the rate of formation of perovskite film [29]. Figure $2 \mathrm{c}$ and d presents the morphologies of samples annealed at $90{ }^{\circ} \mathrm{C}$ and $95^{\circ} \mathrm{C}$. The good morphology of these samples is as a result of the complete evaporation of the volatile by-products $\left(\mathrm{CH}_{3} \mathrm{NH}_{3} \mathrm{Ac}\right)$, and the $90{ }^{\circ} \mathrm{C}$ annealing temperature is just sufficient to provide the latent heat of vaporization needed for the complete removal of the byproducts $\left(\mathrm{CH}_{3} \mathrm{NH}_{3} \mathrm{Ac}\right)$.

Figure 3 shows SEM images of perovskite films aged at 0,200 , and $600 \mathrm{~s}$ before annealing at $90{ }^{\circ} \mathrm{C}$ for $5 \mathrm{~min}$. The images show densely packed grains over the entire area and no visible pores are observed in the perovskite films. From the SEM images, the thin films annealed at $90{ }^{\circ} \mathrm{C}$ exhibit a better film coverage, improved grain sizes and crystallinity; however, no noticeable difference in the morphologies of the samples aged at $0-600 \mathrm{~s}$ before annealing at $90{ }^{\circ} \mathrm{C}$ for $5 \mathrm{~min}$. In general, the films annealed at $90{ }^{\circ} \mathrm{C}$ have excellent morphologies.

Figure 4 represents the XRD pattern of the perovskite films annealed at $80,85,90$ and $95^{\circ} \mathrm{C}$, respectively. Films annealed at 80,85 , and $90^{\circ} \mathrm{C}$ show prominent diffraction peaks at 14.19 and 28.45, corresponding to (110) and (220) lattice planes of the perovskite phase of $\mathrm{CH}_{3} \mathrm{NH}_{3} \mathrm{PbI}_{3}$, respectively. The highest peak intensity of perovskite layer is achieved at $90{ }^{\circ} \mathrm{C}$, the peaks (110) and (220) intensity

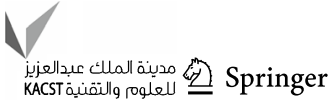



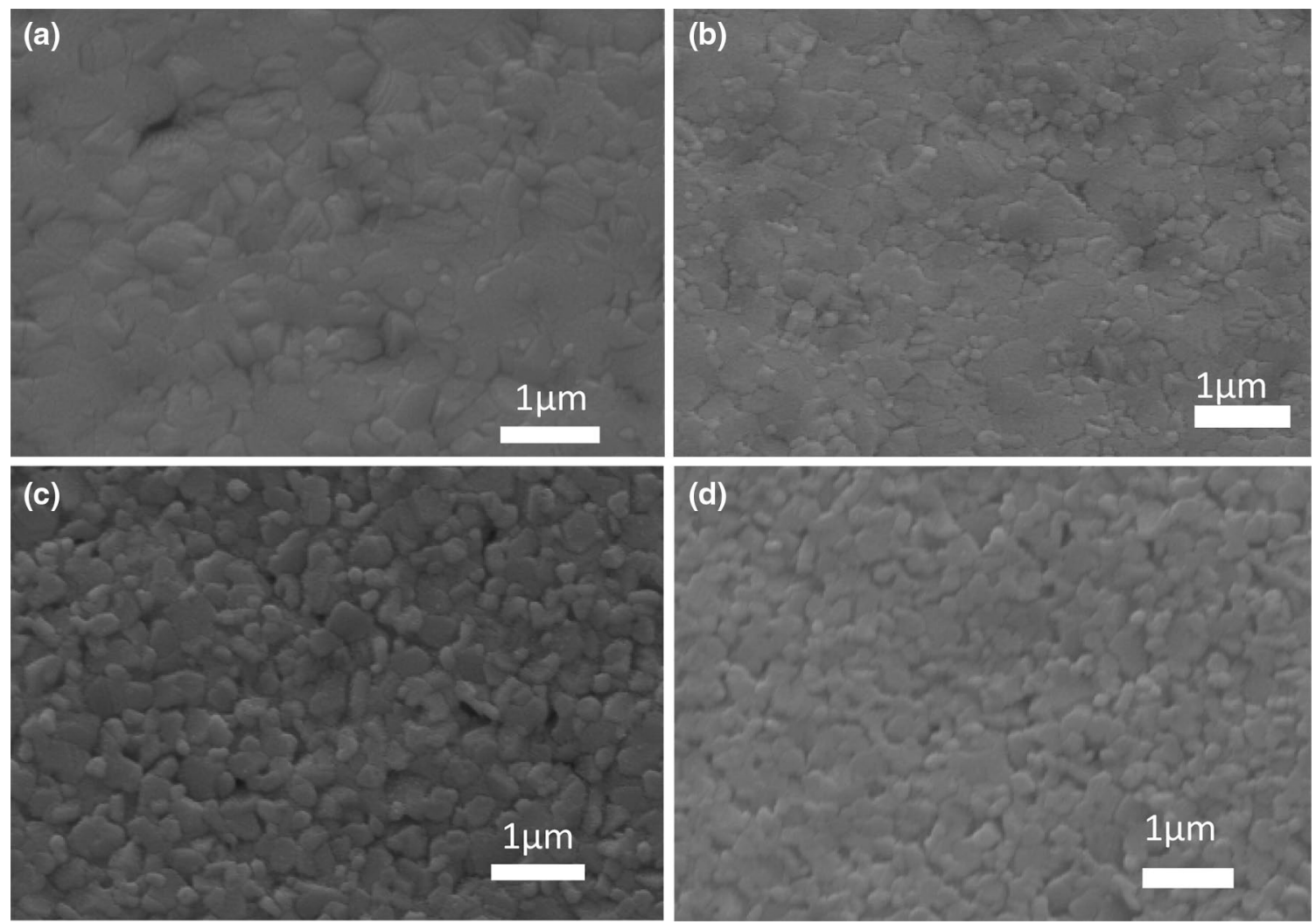

Fig. 2 Surface morphologies of perovskite films annealed at the temperatures of a $80{ }^{\circ} \mathrm{C}$; $\mathbf{b} 85^{\circ} \mathrm{C}$; $\mathbf{c} 90^{\circ} \mathrm{C}$; and $\mathbf{d} 95^{\circ} \mathrm{C}$, respectively, for 5 min
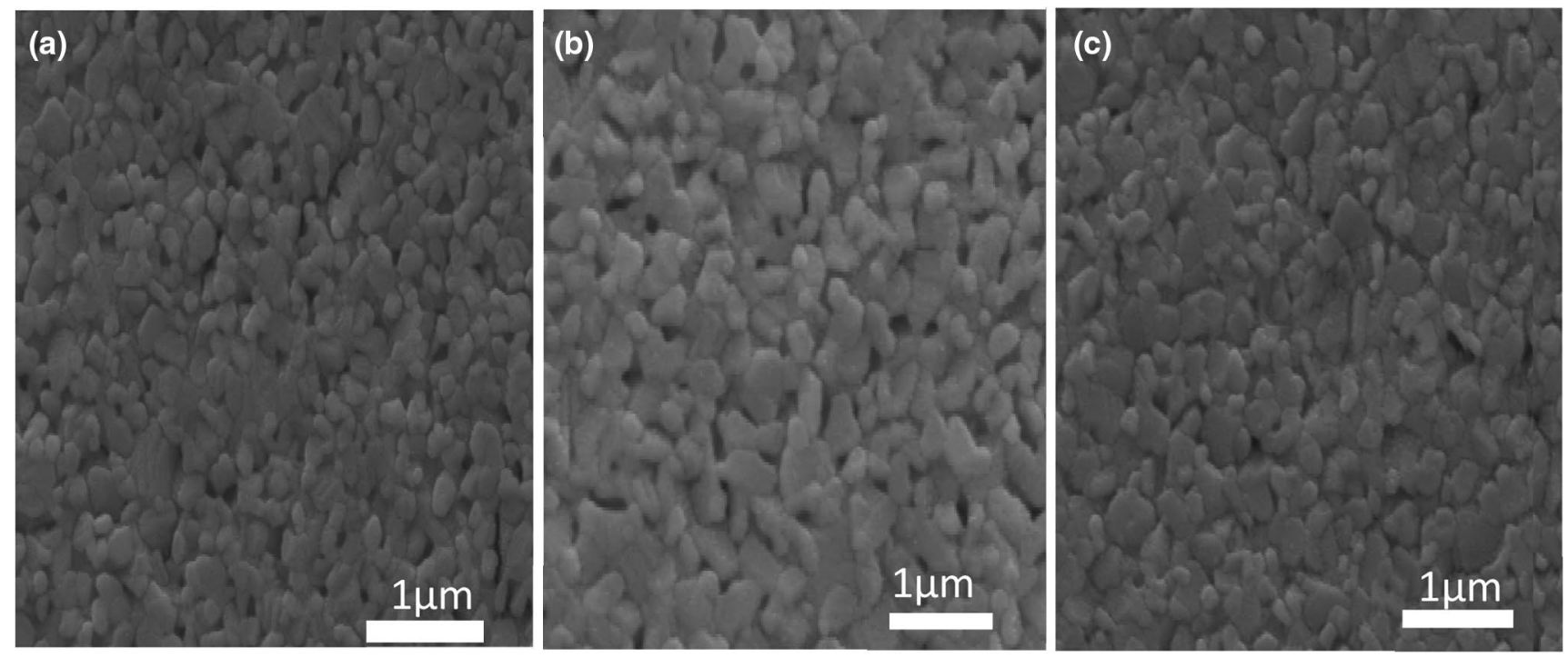

Fig. 3 SEM images of films aged at different time of a $0 \mathrm{~s}$; b $200 \mathrm{~s}$ and $\mathbf{c} 600 \mathrm{~s}$, before thermal annealing at $90{ }^{\circ} \mathrm{C}$ for $5 \mathrm{~min}$

of Fig. 4 increase with increase in temperature up to the optimal temperature at $90{ }^{\circ} \mathrm{C}$, beyond this temperature the intensity of peaks (110) and (220) decreased, indicating that the crystallinity of the perovskite layer improves with temperature until the optimal temperature of $90^{\circ} \mathrm{C}$.
This is consistent with the results obtained from the SEM images (see Fig. 5) which show that the optimal pre-anneal aging time is $200 \mathrm{~s}$ and also corresponded to the highest peak intensities of (110) and (220), respectively. The XRD results show that the aging process has an influence on the 


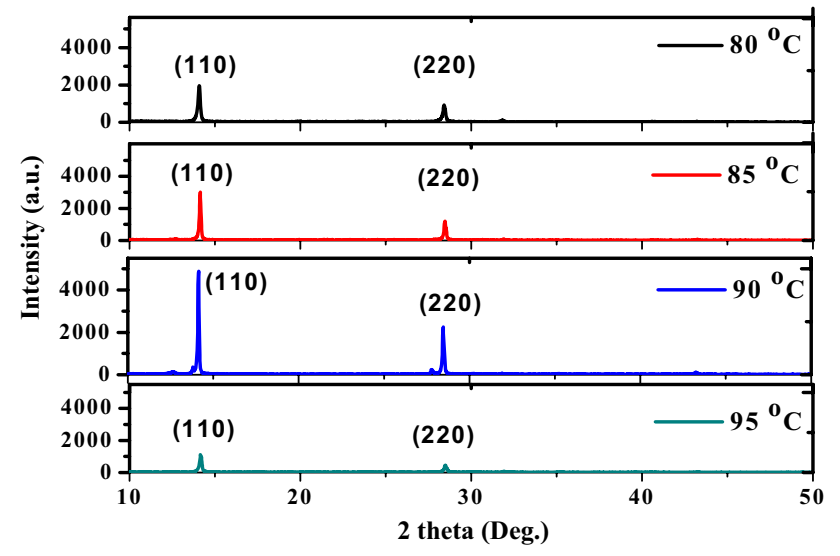

Fig. 4 XRD patterns of the films annealed at $80{ }^{\circ} \mathrm{C}, 85^{\circ} \mathrm{C}, 90^{\circ} \mathrm{C}$ and $95{ }^{\circ} \mathrm{C}$

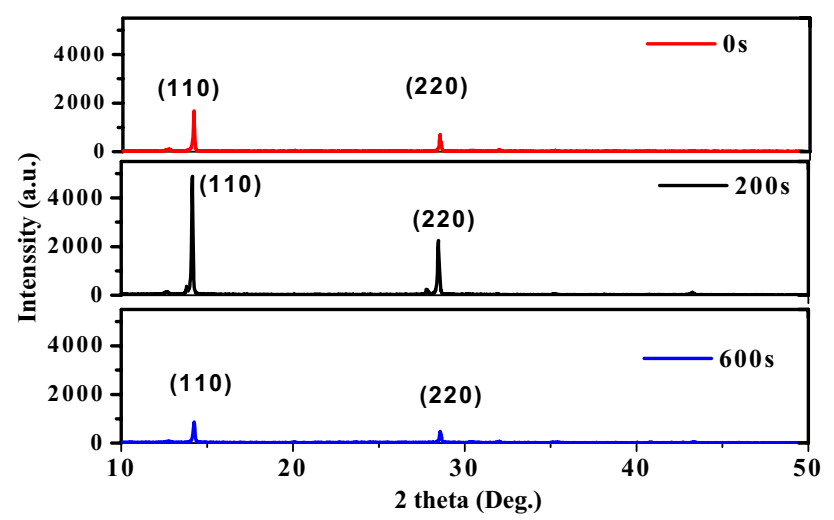

Fig. 5 XRD patterns of the films aged at $0 \mathrm{~s}, 200 \mathrm{~s}$, and $600 \mathrm{~s}$ before annealing at $90^{\circ} \mathrm{C}$ for $5 \mathrm{~min}$

peak intensity of the perovskite film. However, a further increase in the aging time decreases the (110) and (220) peak intensities of the perovskite film. The pre-annealing aging process allows for nucleation to take place at room temperature. During the later stage of the spin coating and during the pre-annealing aging process the film changes color gradually from transparent to reddish-brown. This shows that nucleation partly takes place during the later stages of the spin coating and during the pre-annealing aging process. Therefore, from the changes observed in the film, it is believed that perovskite nucleation partially takes place during pre-annealing aging and leads to the reduction in the amount of $\mathrm{CH}_{3} \mathrm{NH}_{3} \mathrm{Ac}$ that will be evaporated out of the film during the thermal annealing process. The gradual removal of a small quantity of $\mathrm{CH}_{3} \mathrm{NH}_{3} \mathrm{Ac}$ during annealing leads to an improvement in the grain growth of the film as it is observed in the XRD peak intensity of the perovskite. The effect of the pre-annealing aging is clearly observed in the XRD pattern in Fig. 5. These results indicate that controlling the pre-annealing aging has an impact on the quality of perovskite film, which is due to the controlled rate of the removal of $\mathrm{CH}_{3} \mathrm{NH}_{3} \mathrm{Ac}$. The rate of removal of $\mathrm{CH}_{3} \mathrm{NH}_{3} \mathrm{Ac}$ has a great contribution in the perovskite film formation [29].

The Scherrer's equation is adopted in calculating the crystal size from the XRD patterns. The (110) peak from Fig. 4 indicates that the full width at half maximum (FWHM) decreases with increase in the annealing temperature from 80 to $90{ }^{\circ} \mathrm{C}$, which translate into an increase in crystallite size with increase in the annealing temperature. The highest grain size is obtained at $90^{\circ} \mathrm{C}$ and decreases with an increase in temperature above $90{ }^{\circ} \mathrm{C}$; (see supporting document; Table S2) this is due to the complete removal of $\mathrm{CH}_{3} \mathrm{NH}_{3} \mathrm{Ac}$ from the film and providing good crystallinity at $90{ }^{\circ} \mathrm{C}$. This also agrees with SEM images in Fig. 3. The samples aged at $200 \mathrm{~s}$ show a slight increase in the grain sizes compared to those aged at $0 \mathrm{~s}$ and $600 \mathrm{~s}$, respectively (Table S3).

Figure 6 represents UV-Vis spectra of the $\mathrm{CH}_{3} \mathrm{NH}_{3} \mathrm{PbI}_{3}$ films fabricated on glass substrates with annealing temperatures of $80,85,90$, and $95^{\circ} \mathrm{C}$. The high absorbance observed for film annealed at $80^{\circ} \mathrm{C}$ can be ascribed to the development of pinholes and to the poor crystal formation of the perovskite film and this is also noticed in the SEM images. Figure 7a shows the absorbance spectra of films aged after spin coating before annealing at $90{ }^{\circ} \mathrm{C}$ for $5 \mathrm{~min}$; however, no noticeable difference in the optical absorbance of samples derived from different pre-annealing aging time. These results show that pre-annealing aging has no effect on the optical absorption.

To further understand the effect of pre-annealing aging on the performance of perovskite films, TCPL spectra and steady-state photoluminescence (PL) spectra characterization is done. The steady-state PL spectra of the perovskite films deposited on glass show that the films aged at a different time show the same peak position, as shown in Fig. 8a. No red-shift or blue-shift photoluminescence spectra are observed; this implies that there is no change in the band gap and the grain size of the perovskite films aged at a different time. Time-resolved photoluminescence has been used extensively in perovskite solar cell to investigate the charge carrier dynamics $[3,4]$. Figure $8 b$ shows the TCPL spectra of the samples aged at a different time. The observed PL decays are fitted with two exponential decay curves to yield the lifetime of excitons or carriers according to the onedimensional diffusion model, as summarized in supporting information (Table S1). The fast decay component $(\tau 1)$ and the slow decay component $(\tau 2)$ could be attributed to nonradiative recombination and free carriers recombination, respectively [3]. The PL lifetimes for perovskite film derived from $200 \mathrm{~s}$ pre-annealing aging time are $\tau 1=1.54 \mathrm{~ns}$ and $\tau 2=37.66 \mathrm{~ns}$; both values of the lifetime are slightly higher compared to the samples aged at 0 and $600 \mathrm{~s}$. 

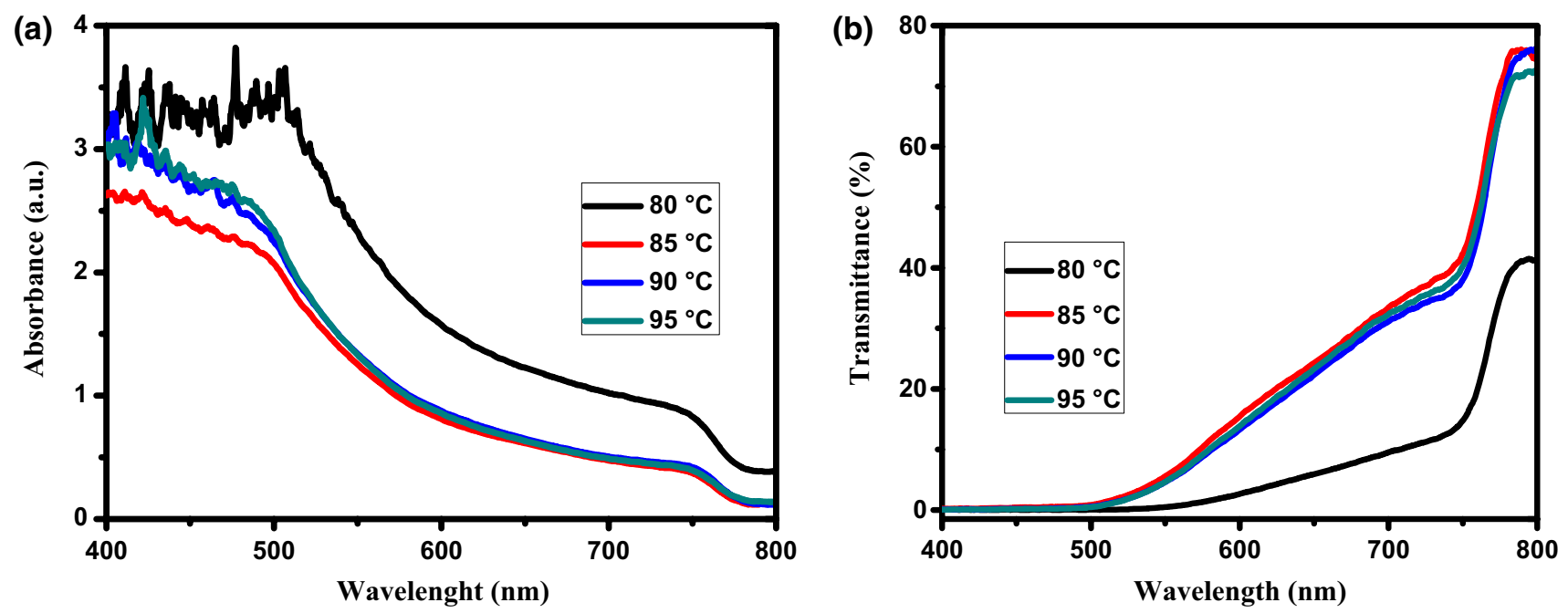

Fig. 6 a Absorption and $\mathbf{b}$ transmittance spectra of perovskite films annealed at different temperatures
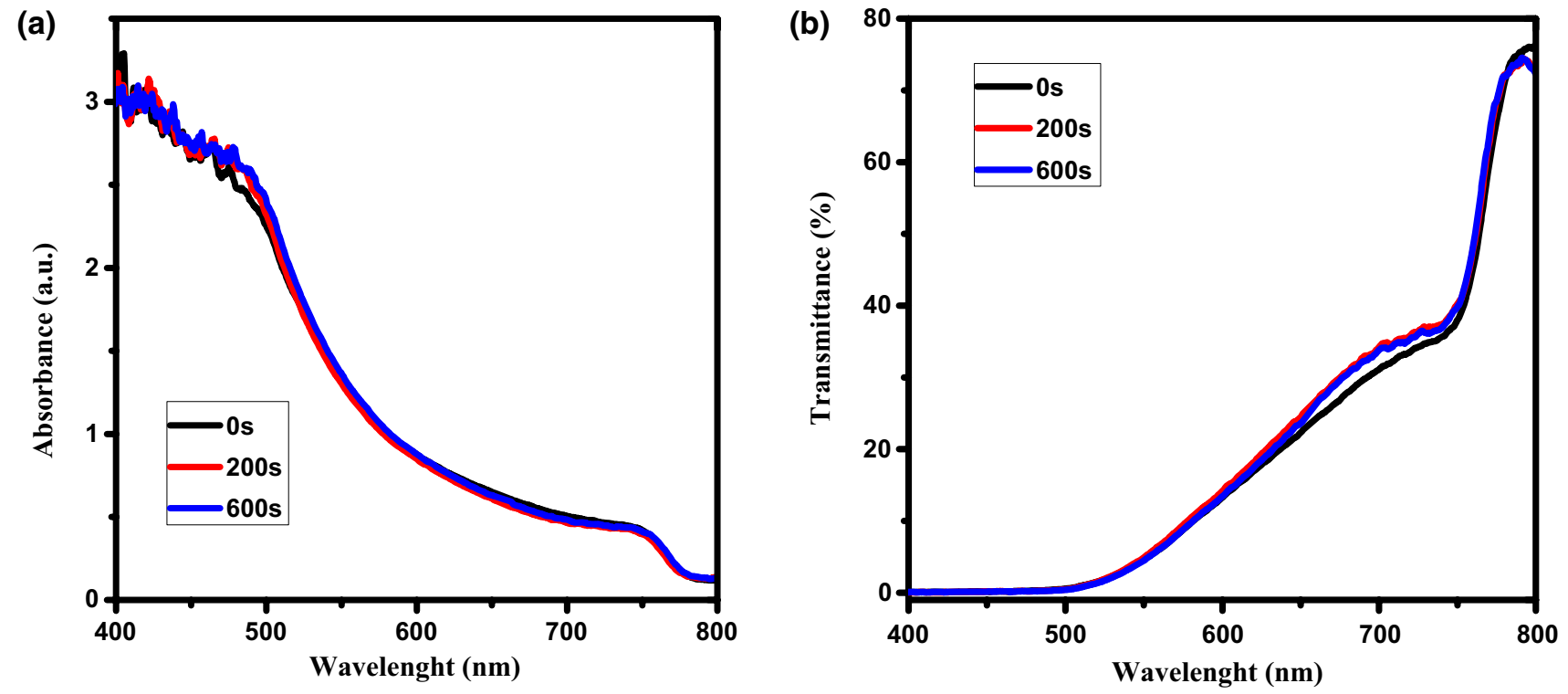

Fig. 7 a Absorption and $\mathbf{b}$ transmittance spectra of perovskite films annealed at $90{ }^{\circ} \mathrm{C}$ and aged at different time

A planar heterojunction architecture was adopted as presented in Fig. 1b to study the impact of pre-annealing aging on the photovoltaic performance of the perovskite solar cell with dehydrated lead acetate $\mathrm{Pb}(\mathrm{Ac})_{2}$ as the source materials. The perovskite layer $\left(\mathrm{CH}_{3} \mathrm{NH}_{3} \mathrm{PbI}_{3}\right)$ is sandwiched between the hole transport layer PEDOT:PSS and the electron transport layer PCBM. When the light enters the multilayered device from the glass/ITO side, the photoactive layer absorbs the photons to produce excitons and mobile charge carriers. In a simple thin-film planar heterojunction structure-based PV devices, it is possible for materials with long diffusion length to have the charge carriers to migrate through the entire photoactive layer.
Different thermal annealing temperatures and prethermal annealing aging time were considered in fabricating the device with a structure of glass/ITO/PEDOT:PSS/ $\mathrm{CH}_{3} \mathrm{NH}_{3} \mathrm{PbI}_{3} / \mathrm{PCMB} / \mathrm{Ag}$. The $J-V$ curves of devices annealed at $80{ }^{\circ} \mathrm{C}, 85^{\circ} \mathrm{C}, 90{ }^{\circ} \mathrm{C}$ and $95{ }^{\circ} \mathrm{C}$ are shown in Fig. 9. The device characteristics shown in Table 1 reveal that devices annealed at $90{ }^{\circ} \mathrm{C}$ have the best performing PCE of $10.8 \%$ and sample annealed at $80^{\circ} \mathrm{C}$ has the lowest PCE of $5.3 \%$. The low PCE in the devices annealed at 80 and $85{ }^{\circ} \mathrm{C}$ is as a result of the incomplete removal of the $\mathrm{CH}_{3} \mathrm{NH}_{3} \mathrm{Ac}$ from the film. This results in the poor crystal growth and defects in the films as it is observed in the SEM images (Fig. 2a, b), these defects serve as recombination 

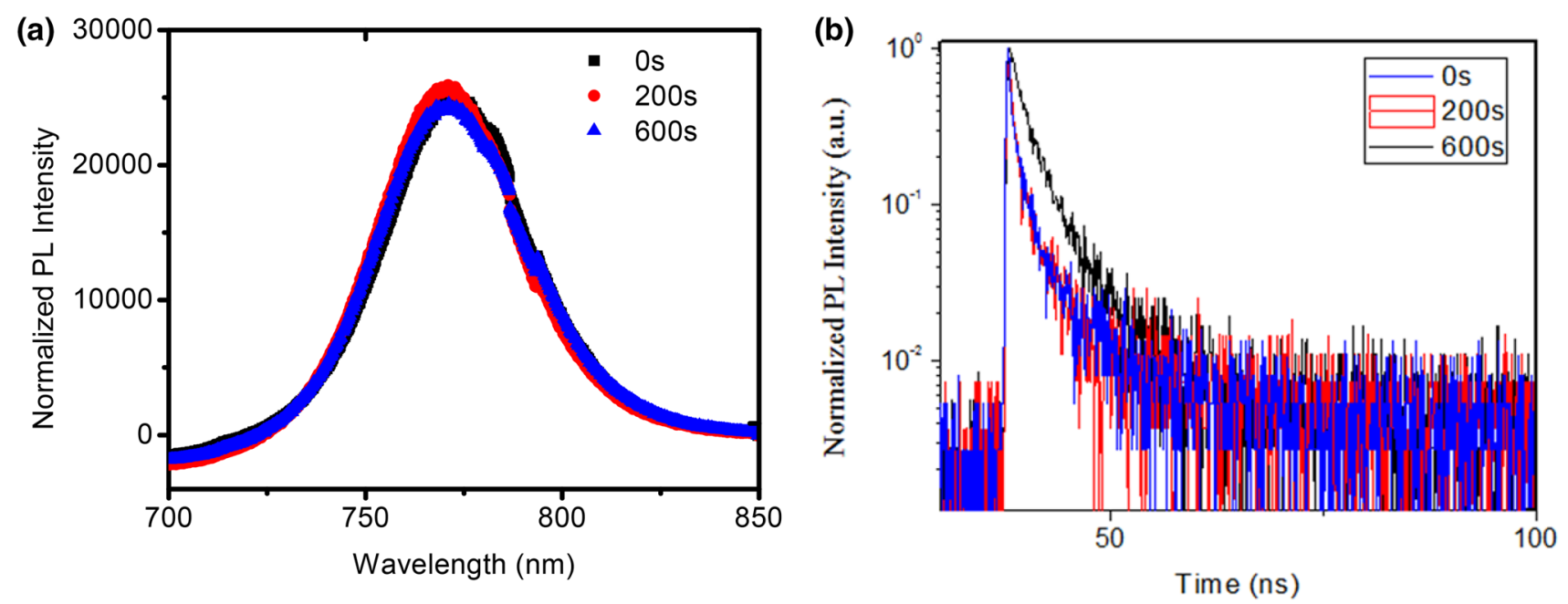

Fig. 8 a Steady-state PL spectra and $\mathbf{b}$ time-resolved PL curves of perovskite films prepared from solution derived from different pre-annealing aging time. All the samples are annealed at $90{ }^{\circ} \mathrm{C}$ for $5 \mathrm{~min}$

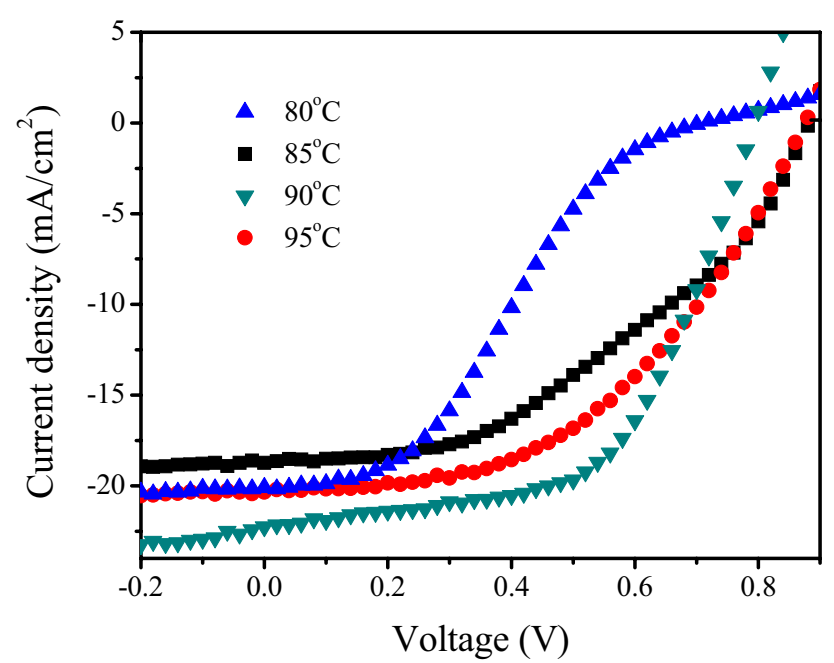

Fig. $9 J-V$ curves derived from different annealing temperatures

Table 1 Photovoltaic properties of devices obtained from annealing temperatures of $80{ }^{\circ} \mathrm{C}, 85^{\circ} \mathrm{C}, 90^{\circ} \mathrm{C}$ and $95^{\circ} \mathrm{C}$, respectively

\begin{tabular}{llllr}
\hline $\begin{array}{l}\text { Temperature } \\
\left({ }^{\circ} \mathrm{C}\right)\end{array}$ & Voc $(\mathrm{V})$ & $\mathrm{Jsc}\left(\mathrm{mA} / \mathrm{cm}^{2}\right)$ & FF $(\%)$ & PCE $(\%)$ \\
\hline 80 & 0.71 & 20.09 & 33.50 & 4.80 \\
85 & 0.88 & 18.73 & 42.40 & 7.00 \\
90 & 0.90 & 19.50 & 61.10 & 10.80 \\
95 & 0.87 & 20.30 & 48.10 & 8.60 \\
\hline
\end{tabular}

sites for the charge carriers and directly lead to low PCE. The S-shape characteristics of the $J-V$ curve observed for the device annealed at $80{ }^{\circ} \mathrm{C}$ could be as a result of the

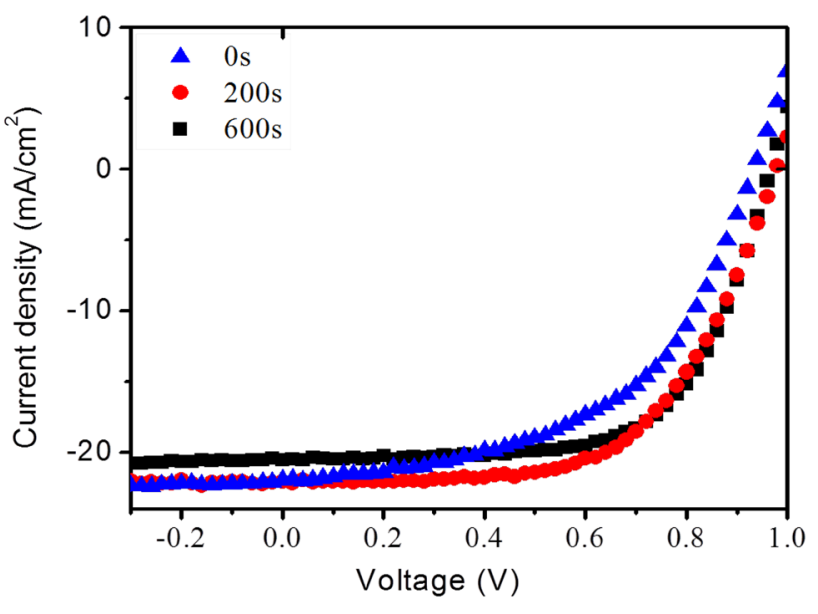

Fig. $10 J-V$ curves of devices obtained with different aging time

Table 2 Photovoltaic properties of devices obtained from pre-annealing aging of $0 \mathrm{~s}, 200 \mathrm{~s}$ and $600 \mathrm{~s}$, respectively, before annealing at $90{ }^{\circ} \mathrm{C}$ for $5 \mathrm{~min}$

\begin{tabular}{cllll}
\hline Aging time (s) & Voc $(\mathrm{V})$ & $\mathrm{Jsc}\left(\mathrm{mA} / \mathrm{cm}^{2}\right)$ & FF $(\%)$ & PCE (\%) \\
\hline 0 & 0.94 & 20.71 & 63.00 & 10.80 \\
200 & 0.98 & 22.50 & 60.00 & 13.02 \\
600 & 0.97 & 20.52 & 65.00 & 12.84 \\
\hline
\end{tabular}

imbalance of charge carrier mobilities in planar heterojunction solar cells [34], electrons and holes cannot be extracted sufficiently fast due to poor crystal growth of the device annealed at $80{ }^{\circ} \mathrm{C}$. The concentration of the charge carriers at the interface of the electron transport layer and the hole 

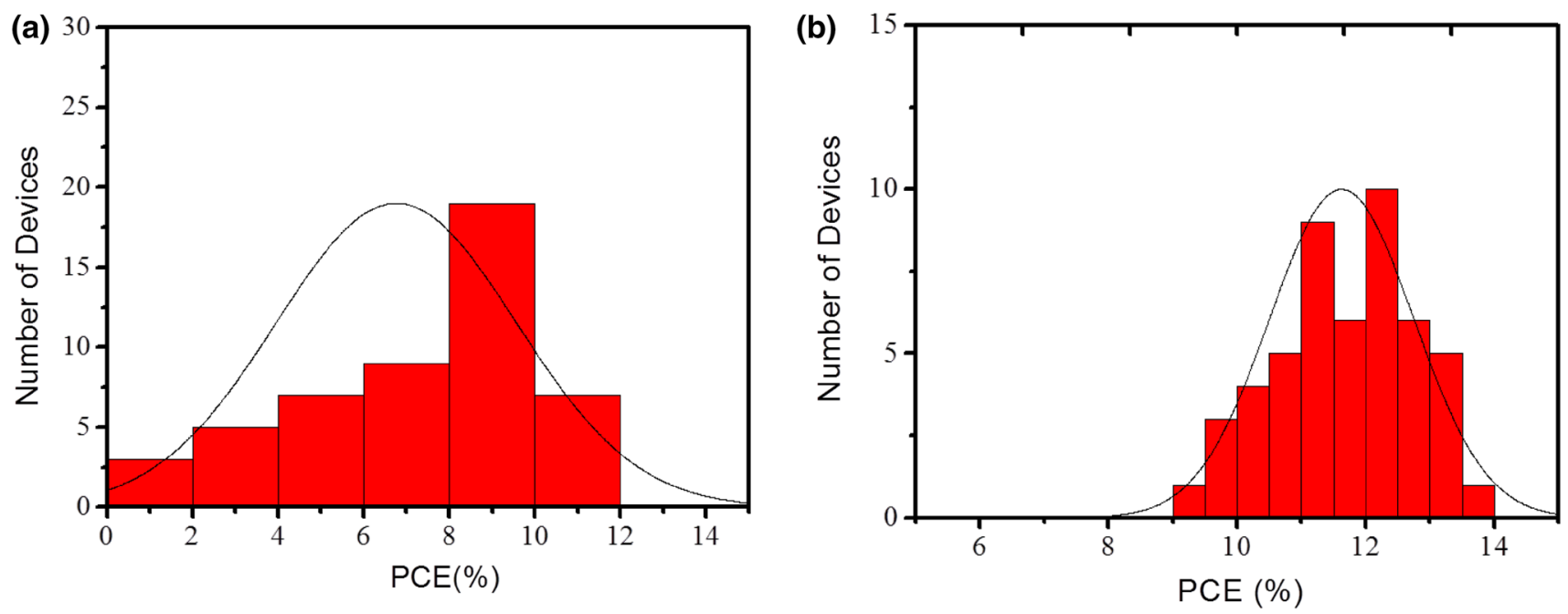

Fig. 11 PCE histogram of 50 devices derived from a annealing immediately after spin coating and $\mathbf{b}$ aging after spin coating before annealing

transport layer is increased which leads to a high probability of recombination and hence a low fill factor (FF). The charge transport properties of the active layer are responsible for the $S$-shape $J-V$ curve. In contrast, the improved PCE in the devices annealed at $90{ }^{\circ} \mathrm{C}$ and $95{ }^{\circ} \mathrm{C}$ is as a result of complete evaporation of the $\mathrm{CH}_{3} \mathrm{NH}_{3} \mathrm{Ac}$ from the film. Figure 10 shows the $J-V$ curves of samples aged at 0,200 , and $600 \mathrm{~s}$ before annealing at $90{ }^{\circ} \mathrm{C}$ for $5 \mathrm{~min}$, results from Fig. 10 and Table 2 show that the best PCE of $13.02 \%$ is obtained for a $200 \mathrm{~s}$ pre-annealing aging time. The increase in the PCE is due to the partial removal of $\mathrm{CH}_{3} \mathrm{NH}_{3} \mathrm{Ac}$ during aging and this results in the gradual removal of small amount of $\mathrm{CH}_{3} \mathrm{NH}_{3} \mathrm{Ac}$ during thermal annealing. In the case of the unaged devices that are annealed immediately after spin coating, there is an abrupt removal of a large amount of $\mathrm{CH}_{3} \mathrm{NH}_{3} \mathrm{Ac}$ creating defects in the devices and these defects lead to the recombination of charge carriers before getting to their respective transport layers.

Figure $11 \mathrm{a}, \mathrm{b}$ shows the PCE histogram of 50 devices derived from annealing immediately after spin coating and aging after spin coating before annealing, respectively. The results from Fig. 11b show that devices derived from preannealing aging show higher repeatability. The justification for the high reproducibility in these devices is due to the fact that during aging nucleation partly takes place and also the partial evaporation of the $\mathrm{CH}_{3} \mathrm{NH}_{3} \mathrm{Ac}$ takes place. Thus, during the thermal anneal, small quantities of $\mathrm{CH}_{3} \mathrm{NH}_{3} \mathrm{Ac}$ are gradually removed from the film and lead to an improved grain growth, high PCE, and high repeatability. The low reproducibility in the unaged devices is due to the abrupt removal of a large amount of $\mathrm{CH}_{3} \mathrm{NH}_{3} \mathrm{Ac}$ during the thermal anneal. This creates defects in the films which provide recombination sites for the mobile charge carriers and in some cases complete device failure.

\section{Conclusions}

The impact of pre-annealing aging on the photovoltaic properties of perovskite solar cells fabricated from dehydrated lead acetate $\left(\mathrm{Pb}(\mathrm{Ac})_{2}\right)$-based precursor using a single-step deposition method was investigated. The as-prepared film exhibits uniform coverage with lesser pinholes with excellent morphology and crystallinity. The PCE of solar cell devices derived from aging after spin coating before thermal annealing averages $13.02 \%$ with high repeatability, which is far higher than devices obtained from thermal annealing immediately after the spin with a PCE of $10.8 \%$ and lower repeatability. The reason for the improved performance and higher reproducibility is a result of the gradual removal of small amounts of $\mathrm{CH}_{3} \mathrm{NH}_{3} \mathrm{Ac}$ during thermal anneal for the aged samples as compared to the abrupt removal of $\mathrm{CH}_{3} \mathrm{NH}_{3} \mathrm{Ac}$ for the unaged samples. Our findings suggest that pre-annealing aging has a great impact on the performance of solar cell devices derived from dehydrated lead acetate used as the source materials.

Acknowledgements This research was funded by Pan African Materials Institute (PAMI) through funding from the World Bank to whom the authors are grateful.

Open Access This article is distributed under the terms of the Creative Commons Attribution 4.0 International License (http://creativeco mmons.org/licenses/by/4.0/), which permits unrestricted use, distribution, and reproduction in any medium, provided you give appropriate credit to the original author(s) and the source, provide a link to the Creative Commons license, and indicate if changes were made. 


\section{References}

1. Kim, H.-S., Lee, C.-R., Im, J.-H., Lee, K.-B., Moehl, T., Marchioro, A., Moon, S.-J., Humphry-Baker, R., Yum, J.-H., Moser, J.E., Gratzel, M., Park, N.-G.: Lead Iodide perovskite sensitized all-solid-state submicron thin film mesoscopic solar cell with efficiency exceeding 9\%. Sci Rep 2(591), 1-7 (2012). https://doi. org/10.1038/srep00591

2. Lee, M.M., Teuscher, J., Miyasaka, T., Murakami, T.N., Snaith, H.J.: Efficient hybrid solar cells based on meso-superstructured organometal halide perovskites. Reports 338, 643-648 (2012). https://doi.org/10.1126/science.1228604

3. Stranks, S.D., Eperon, G.E., Grancini, G., Menelaou, C., Alcocer, M.J.P., Leijtens, T., Herz, L.M., Petrozza, A., Snaith, H.J.: Electron-hole diffusion lengths exceeding 1 micrometer in an organometal trihalide perovskite absorber. Reports 342, 341-345 (2013). https://doi.org/10.1126/science.1243982

4. Xing, G., Mathews, N., Lim, S.S., Lam, Y.M., Mhaisalkar, S., Sum, T.C.: Long-range balanced electron- and hole-transport lengths in organic-inorganic $\mathrm{CH}_{3} \mathrm{NH}_{3} \mathrm{PbI}_{3}$. Science 342, 344348 (2013). https://doi.org/10.1126/science. 1243167

5. Kojima, A., Teshima, K., Shirai, Y., Miyasaka, T.: Organometal halide perovskites as visible-light sensitizers for photovoltaic cells. J Am Chem Soc 131, 6050-6051 (2009). https://doi. org/10.1021/ja809598r

6. Im, J.-H., Lee, C.-R., Lee, J.-W., Park, S.-W., Park, N.-G.: 6.5\% efficient perovskite quantum-dot-sensitized solar cell. Nanoscale 3, 4088-4093 (2011). https://doi.org/10.1039/c1nr10867k

7. Wang, K.C., Jeng, J.Y., Shen, P.O., Chang, Y.C., Diau, E.W.G., Tsai, C.H., Chao, T.Y., Hsu, H.C., Lin, P.Y., Chen, P., Guo, T.F., Wen, T.C.: P-type mesoscopic nickel oxide/organometallic perovskite heterojunction solar cells. Sci Rep 4, 1-8 (2014). https://doi.org/10.1038/srep04756

8. Ye-Jin, J., Lee, S., Kang, R., Kim, J.-E., Yeo, J.-S., Lee, S.-H., Kim, S.-S., Yun, J.-M., Kim, D.-Y.: Planar heterojunction perovskite solar cells with superior reproducibility. Sci Rep 4, 1-7 (2014). https://doi.org/10.1038/srep06953

9. Zhou, H., Chen, Q., Li, G., Luo, S., Song, T., Duan, H.-S., Hong, Z., You, J., Liu, Y., Yang, Y.: Interface engineering of highly efficient perovskite solar cells. Res Rep 345, 542-546 (2014). https://doi.org/10.1126/science.1254050

10. Liu, M., Johnston, M.B., Snaith, H.J.: Efficient planar heterojunction perovskite solar cells by vapour deposition. Nature 501, 395-398 (2013). https://doi.org/10.1038/nature12509

11. Jung, H.S., Park, N.G.: Perovskite solar cells: from materials to devices. Small 11, 1-16 (2015). https://doi.org/10.1002/ smll.201402767

12. Xu, J., Buin, A., Ip, A.H., Li, W., Voznyy, O., Comin, R., Yuan, M., Jeon, S., Ning, Z., McDowell, J.J., Kanjanaboos, P., Sun, J.P., Lan, X., Quan, L.N., Kim, D.H., Hill, I.G., Maksymovych, P., Sargent, E.H.: Perovskite-fullerene hybrid materials suppress hysteresis in planar diodes. Nat Commun 6, 1-8 (2015). https:// doi.org/10.1038/ncomms8081

13. Docampo, P., Ball, J.M., Darwich, M., Eperon, G.E., Snaith, H.J.: Efficient organometal trihalide perovskite planar-heterojunction solar cells on flexible polymer substrates. Nat Commun 4, 1-6 (2013). https://doi.org/10.1038/ncomms3761

14. Chen, Q., Zhou, H., Hong, Z., Luo, S., Duan, H., Wang, H., Liu, Y., Li, G., Yang, Y.: Planar heterojunction perovskite solar cells via vapor-assisted solution process. J Am Chem Soc 136(2), 3-6 (2014). https://doi.org/10.1021/ja411509g

15. Heo, J.H., Im, S.H., Noh, J.H., Mandal, T.N., Lim, C.S., Chang, J.A., Lee, Y.H., Kim, H.J., Sarkar, A., Nazeeruddin, M.K., Grätzel, M., Seok, S.I.: Efficient inorganic-organic hybrid heterojunction solar cells containing perovskite compound and polymeric hole conductors. Nat Photonics 7, 1-6 (2013). https ://doi.org/10.1038/nphoton.2013.80

16. Burschka, J., Pellet, N., Moon, S.J., Humphry-Baker, R., Gao, P., Nazeeruddin, M.K., Grätzel, M.: Sequential deposition as a route to high-performance perovskite-sensitized solar cells. Res Lett (2013). https://doi.org/10.1038/nature12340

17. Stranks, S.D., Nayak, P.K., Zhang, W., Stergiopoulos, T., Snaith, H.J.: Formation of thin films of organic-inorganic perovskites for high-efficiency solar cells. Angew Chem Int Ed 54, 2-11 (2015). https://doi.org/10.1002/anie.201410214

18. Zhang, W., Saliba, M., Moore, D.T., Pathak, S.K., Hörantner, M.T., Stergiopoulos, T., Stranks, S.D., Eperon, G.E., Alexander-Webber, J.A., Abate, A., Sadhanala, A., Yao, S., Chen, Y., Friend, R.H., Estroff, L.A., Wiesner, U., Snaith, H.J.: Ultrasmooth organic-inorganic perovskite thin-film formation and crystallization for efficient planar heterojunction solar cells. Nat Commun 6, 1-10 (2015). https://doi.org/10.1038/ncomms7142

19. Aldibaja, F.K., Badia, L., Mas-Marzá, E., Sánchez, R.S., Barea, E.M., Mora-Sero, I.: Effect of different lead precursors on perovskite solar cell performance and stability. J Mater Chem A 3, 9194-9200 (2015). https://doi.org/10.1039/c4ta06198e

20. Ball, J.M., Lee, M.M., Hey, A., Snaith, H.J.: Low-temperature processed meso-superstructured to thin-film perovskite solar cells. Energy Environ Sci 6, 1739-1743 (2013). https://doi.org/10.1039/ c3ee $40810 \mathrm{~h}$

21. Balaji, G., Joshi, P.H., Abbas, H.A., Zhang, L., Kottokkaran, R., Samiee, M., Noack, M., Dalal, V.L.: $\mathrm{CH}_{3} \mathrm{NH}_{3} \mathrm{PbI}_{3}$ from noniodide lead salts for perovskite solar cells via the formation of $\mathrm{PbI}_{2}$. Phys Chem Chem Phys (2012). https://doi.org/10.1039/ c5cp00073d

22. Dimesso, L., Dimamay, M., Hamburger, M., Jaegermann, W.: Properties of $\mathrm{CH}_{3} \mathrm{NH}_{3} \mathrm{PbX}_{3}(\mathrm{X}=\mathrm{I}, \mathrm{Br}, \mathrm{Cl})$ powders as precursors for organic/inorganic solar cells. Chem Mater 26, 6762-6769 (2014). https://doi.org/10.1021/cm503240k

23. Xiao, Z., Dong, Q., Bi, C., Shao, Y., Yuan, Y.: Solvent annealing of perovskite-induced crystal growth for photovoltaic-device effi ciency enhancement. Adv Mater 26, 6503-6509 (2014). https:// doi.org/10.1002/adma.201401685

24. Jeon, N.J., Noh, J.H., Kim, Y.C., Yang, W.S., Ryu, S., Seok, S.I.: Solvent engineering for high-performance inorganic-organic hybrid perovskite solar cells. Nat Mater (2014). https://doi. org/10.1038/nmat4014

25. Xiao, M., Huang, F., Huang, W., Dkhissi, Y., Zhu, Y., Etheridge, J., Gray-Weale, A., Bach, U., Cheng, Y.B., Spiccia, L.: A fast deposition-crystallization procedure for highly efficient lead iodide perovskite thin-film solar cells. Angew Chem Int Ed 126, 1-7 (2014). https://doi.org/10.1002/anie.201405334

26. Xie, F.X., Zhang, D., Su, H., Ren, X., Wong, K.S., Grätzel, M., Choy, W.C.H.: Vacuum-assisted thermal annealing of $\mathrm{CH}_{3} \mathrm{NH}_{3} \mathrm{PbI}_{3}$ for highly stable and efficient perovskite solar cells. ACS Nano 9, 639-646 (2015). https://doi.org/10.1021/nn505978r

27. Zuo, L., Gu, Z., Ye, T., Fu, W., Wu, G., Li, H., Chen, H.: Enhanced photovoltaic performance of $\mathrm{CH}_{3} \mathrm{NH}_{3} \mathrm{PbI}_{3}$ perovskite solar cells through interfacial engineering using self-assembling monolayer. J Am Chem Soc (2015). https://doi.org/10.1021/ja512518r

28. Liang, P.W., Liao, C.Y., Chueh, C.C., Zuo, F., Williams, S.T., Xin, X.K., Lin, J., Jen, A.K.Y.: Additive enhanced crystallization of solution-processed perovskite for highly efficient planarheterojunction solar cells. Adv Mater 26, 3748-3754 (2014). https ://doi.org/10.1002/adma.201400231

29. Chen, Y., Yerramilli, A., Shen, Y., Zhao, Z., Alford, T.: Effect of excessive $\mathrm{Pb}$ content in the precursor solutions on the properties of the lead acetate derived $\mathrm{CH}_{3} \mathrm{NH}_{3} \mathrm{PbI}_{3}$ perovskite solar cells. Sol Energy Mater Sol Cells 174, 478-484 (2018). https:// doi.org/10.1016/j.solmat.2017.09.039 
30. Qing, J., Chandran, H.T., Xue, H.T., Guan, Z.Q., Liu, T.L., Tsang, S.W., Lo, M.F., Lee, C.S.: Simple fabrication of perovskite solar cells using lead acetate as lead source at low temperature. Org Electron Phys Mater Appl 27, 12-17 (2015). https://doi. org/10.1016/j.orgel.2015.08.021

31. Li, C., Guo, Q., Qiao, W., Chen, Q., Ma, S., Pan, X., Wang, F., Yao, J., Zhang, C., Xiao, M., Dai, S., Tan, Z.: Efficient lead acetate sourced planar heterojunction perovskite solar cells with enhanced substrate coverage via one-step spin-coating. Org Electron Phys Mater Appl 33, 194-200 (2016). https://doi.org/10.1016/j.orgel .2016.03.017

32. Qing, J., Chandran, H.T., Cheng, Y.H., Liu, X.K., Li, H.W., Tsang, S.W., Lo, M.F., Lee, C.S.: Chlorine incorporation for enhanced performance of planar perovskite solar cell based on lead acetate precursor. ACS Appl Mater Interfaces 7, 23110-23116 (2015). https://doi.org/10.1021/acsami.5b06819
33. Moore, D.T., Sai, H., Tan, K.W., Smilgies, D.M., Zhang, W., Snaith, H.J., Wiesner, U., Estroff, L.A.: Crystallization kinetics of organic-inorganic trihalide perovskites and the role of the lead anion in crystal growth. J Am Chem Soc 137, 2350-2358 (2015). https://doi.org/10.1021/ja512117e

34. Tress, W., Petrich, A., Hummert, M., Hein, M., Leo, K., Riede, M.: Imbalanced mobilities causing S-shaped IV curves in planar heterojunction organic solar cells. Appl Phys Lett 98, 1-3 (2011). https://doi.org/10.1063/1.3553764

Publisher's Note Springer Nature remains neutral with regard to jurisdictional claims in published maps and institutional affiliations. 